\title{
Acute Effect of Intravenous Ethanol on Electrocardiogram of New Zealand White Rabbits
}

\author{
Jafrin Ara Ahmed ${ }^{1}$, Nawab Nashiruddullah ${ }^{2}$, Juneet Kour ${ }^{1}$ and \\ Dibyendu Chakraborty ${ }^{3} *$
}

${ }^{1}$ Division of Veterinary Physiology and Biochemistry, ${ }^{2}$ Division of Veterinary Pathology,

${ }^{3}$ Division of Animal Genetics \& Breeding, Faculty of Veterinary Sciences and Animal

Husbandry, SKUAST-Jammu, R.S. Pura, Jammu-181102, India

*Corresponding author

\section{Keywords}

Electrocardiogram,

Ethanol, New

Zealand White

rabbit

Article Info

Accepted:

04 January 2019

Available Online:

10 February 2019

\section{A B S T R A C T}

The present study was undertaken to study the effects of intra-venous (i.v.) ethanol (25\%, $50 \%$ and $100 \%$ ) on Electrocardiogram of New Zealand White rabbits. Twelve healthy and clinically normal New Zealand White rabbits of either sex, weighing between 2-3 kg and aged between 1-2 years were selected for the present study. $1 \mathrm{ml}$ of ethanol $(25 \%, 50 \%$ and 100\%) was injected i.v. in the ear vein of the rabbit and ECG recordings were taken for 50 minutes. Rabbits exhibited a significant decrease in heart rate following the injection of $25 \%$ and $50 \%$ ethanol and the heart rate remained significantly $(\mathrm{P}<0.01)$ depressed for a period of 30 minutes. Low P-wave amplitude was observed. QRS amplitudes have increased significantly in $25 \%$ and $50 \%$ ethanol treated group. Increased QRS voltage, and prolonged ventricular activation time, likely represents left ventricular hypertrophy. But QRS amplitude has decreased significantly in 100\% ethanol treatment. T wave amplitudes significantly increase in 25\% and 50\% treatment group and decrease in $100 \%$ treatment group. QT interval indicating the total duration of electrical activity in the ventricles was significantly increased compared with that of control group (50\% treated group).

\section{Introduction}

Ethanol is known to exert significant effects on the electrical characteristics of the myocardium (Takeda et al., 1984). Ingestion of ethanol causes disturbances of cardiac rhythm and conduction (Marriott and Myerburg, 1974; Ettinger et al., 1976). Bollinger, who introduced the term 'Munich beer heart' in describing cardiac dilatation and hypertrophy secondary to chronic alcoholism (Bollinger, 1884), since then in vivo and in vitro effects of ethanol on heart have extensively been investigated (Altura and Atura, 1989). The study of electrocardiogram (ECG) pattern is very useful in the detection of abnormal heart conditions (Venkateshwarlu et al., 1977). Alcohol consumption causes ECG changes which include cardiac conduction 
abnormalities, prolongation of the QT interval, prolongation of ventricular repolarization and sympathetic stimulation (Rossinen et al., 1999). Sinus tachycardia or a supraventricular arrythmia, commonly atrial fibrillation and non-specific ST-T changes are also observed in alcoholics (Klatsky, 1996). Alcohol alters the endocrinal function like increase in adrenocorticotrophic hormone, oxytocin and electrolytes, which may indirectly causes myocardial damage (Langer, 1992). Therefore, the present study was undertaken to study the acute effects of i.v. ethanol $(25 \%, 50 \%$ and $100 \%)$ on electrocardiogram of rabbit.

\section{Materials and Methods}

Twelve healthy and clinically normal New Zealand White rabbits of either sex, weighing between 2-3 $\mathrm{kg}$ and aged between 1-2 years were used to observe the electrocardiographic changes before and after treatment. The experiment was approved by the Institutional Animal Ethics Committee (IAEC). Prior to ECG recording, the animals were properly restrained and were allowed to stand for 1015 minutes to familiarize it with the experimental ambience. The ECG recordings were made in sternal recumbency as per the method described by Tilley (1979) using a multichannel electrocardiograph (NASAN, NE-3I). Three bipolar standard limb leads (I, II and III) and three unipolar augmented limb leads (aVR, aVL, and aVF) were used to record the electrocardiogram. The ECG machine was calibrated to give $20 \mathrm{~mm}$ deflection per $\mathrm{mv}$ of input and recordings were traced with a paper speed of $50 \mathrm{~mm} / \mathrm{second}$. Site for attachment of electrodes were trimmed with scissors and cardiac gel was applied to increase conductivity. Electrodes were attached with small crocodile clips with flattened teeth as previously described by Ahmed (2002) and were attached directly to the animal's skin proximal to the olecrenon on the caudal aspect of the appropriate forelimb, and over the patellar ligament on the cranial aspect of appropriate hind limb. Then $1 \mathrm{ml}$ of ethanol $(25 \%, 50 \%$ and $100 \%)$ was injected i.v. in the ear vein of the rabbit and ECG recordings were taken for 50 minutes. To compare the ECG changes after injection of $25 \%, 50 \%$ and $100 \%$ ethanol, normal electrocardiogram was recorded beforehand to ensure that the animal was healthy as per Ahmed et al., (2008).

\section{Results and Discussion}

\section{Heart rate}

Rabbits exhibited a significant decrease in heart rate (Table 1) following the addition of $25 \%$ and $50 \%$ ethanol, and the heart rate remained significantly $(\mathrm{P}<0.01)$ depressed for 30 mins period. Similarly, ethanol has been previously shown to slow the heart rate of the invertebrate Ciona intestinalis (Pope and Rowley, 2002). Ethanol is known to elicit a biphasic response, with stimulatory effects produced at lower doses and inhibitory effects at higher doses (Earleywine and Martin, 1993). In the present study addition of $25 \%$ and $50 \%$ ethanol may influence vagal centres of the central nervous system and resulted bradycardia (Samonia and Hakumaki, 1982). Again injection of $100 \%$ ethanol significantly $(\mathrm{P}<0.01)$ increases heart rate, ethanol may inhibit ACh release and decreases cholinergic transmission in these inhibitory neurons, causing increase in the heart rate of rabbits (Carmichael and Israel, 1975; Erickson and Graham, 1973).

\section{Cardiac Axis}

QRS frontal axis in degrees were $90.000 \pm 0.258, \quad 89.000 \pm 0.258 \quad$ and $87.500 \pm 0.342$ before ethanol injection and $87.667 \pm 0.494,86.000 \pm 0.142$ and $86.00 \pm 0.258$ after injection of $25 \%, 50 \%$ and $100 \%$ 
ethanol, respectively (Table 2). Similar findings were also observed by Swathi and Nasar Ahamed (2014) in alcoholic people. Ramanna et al., (2014) found mean $( \pm \mathrm{SD})$ QRS frontal axis $63.10^{\circ} \pm 28.70^{\circ}$ during exercise in control and $58.60^{\circ} \pm 31.00^{\circ}$ in alcoholic persons.

\section{Amplitude of electrocardiographic waves}

"P" waves of amplitude have decreased significantly in all the treated groups (Table 3). Swathi and Nasar Ahamed 2014) also found slight decrese in $\mathrm{P}$ wave amplitude in alcoholics though it was not statistically significant. Venkatesh (2011) also did not observe any significant difference in values of $P$ wave duration and amplitudes. In our present study, low P-wave amplitude may be associated with low LA ( Left atrial) voltage, displaced inter-atrial conduction, and slower conduction velocity, which contributes to short wave lengths and makes the tissue vulnerable to fibrillation ( Park et al., 2016).
QRS amplitudes have increased significantly in ethanol treated group $(25 \%, 50 \%)$. Increased QRS voltage, and prolonged ventricular activation time, likely represents left ventricular hypertrophy in a high percentage of cases (Manning and Smihley, 1964). But QRS amplitude has decreased significantly in $100 \%$ ethanol treatment. $\mathrm{T}$ wave amplitudes significantly increase in $25 \%$ and $50 \%$ treatment group and decrease in $100 \%$ treatment group. It may be due to alterations of sympathetic tone (Kitchin and Neilson, 1972). Robertson (1955) stated that low voltage of the $\mathrm{T}$ waves might be due to early myocardial degeneration or coronary sclerosis.

\section{Duration of electrocardiographic waves}

Duration of electrocardiographic waves has been presented in Table 4. Lorsheyd et al., (2005) showed prolongation of the PR interval and QRS complex after acute ingestion of alcohol.

Table.1 Heart rates after treatment of ethanol (25\%), ethanol (50\%) and ethanol (100\%) (Mean \pm $\mathrm{SE})$

\begin{tabular}{|c|c|c|c|c|c|c|}
\hline & Control & $10 \mathrm{~min}$ & $20 \mathrm{~min}$ & $30 \mathrm{~min}$ & 40 min & $50 \mathrm{~min}$ \\
\hline $\begin{array}{l}\text { Ethanol }(25 \%) \text { treated } \\
\text { group }\end{array}$ & $\begin{array}{l}213.00 \pm \\
0.683\end{array}$ & $\begin{array}{l}200.00 \pm \\
1.291^{* * *}\end{array}$ & $\begin{array}{l}202.500 \pm \\
1.708^{* *}\end{array}$ & $\begin{array}{l}200.667 \pm \\
0.882^{* *}\end{array}$ & $\begin{array}{l}200.000 \pm \\
2.582 * *\end{array}$ & $\begin{array}{l}214.333 \pm \\
1.308 * *\end{array}$ \\
\hline $\begin{array}{l}\text { Ethanol }(50 \%) \text { treated } \\
\text { group }\end{array}$ & $\begin{array}{l}225.83 \pm \\
3.270\end{array}$ & $\begin{array}{l}225.83 \pm \\
2.713\end{array}$ & $\begin{array}{l}214.33 \pm \\
1.308^{*}\end{array}$ & $\begin{array}{l}209.17 \pm \\
3.060^{* *}\end{array}$ & $\begin{array}{l}211.83 \pm \\
1.515^{*}\end{array}$ & $\begin{array}{l}215.17 \pm \\
0.980^{*}\end{array}$ \\
\hline $\begin{array}{l}\text { Ethanol } \\
\text { treated group }\end{array}$ & $\begin{array}{l}213.00 \pm \\
1.308\end{array}$ & $\begin{array}{l}213.00 \pm \\
0.719\end{array}$ & $\begin{array}{l}225.00 \pm \\
3.416^{*}\end{array}$ & $\begin{array}{l}225.00 \pm \\
3.270^{*}\end{array}$ & $\begin{array}{l}214.00 \pm \\
1.167\end{array}$ & $\begin{array}{l}212.00 \pm \\
2.716\end{array}$ \\
\hline
\end{tabular}

Table. 2 Cardiac axes after treatment with ethanol (25\%), ethanol (50\%) and ethanol (100\%) $($ Mean \pm SE)

\begin{tabular}{|c|c|c|c|c|c|c|}
\hline & Control & $10 \mathrm{~min}$ & $20 \mathrm{~min}$ & $30 \mathrm{~min}$ & $40 \mathrm{~min}$ & $50 \mathrm{~min}$ \\
\hline $\begin{array}{l}\text { Ethanol }(25 \%) \text { treated } \\
\text { group }\end{array}$ & $90.000 \pm 0.258$ & $\begin{array}{l}83.167 \pm \\
0.401^{* * *}\end{array}$ & $\begin{array}{l}90.000 \pm \\
0.342\end{array}$ & $\begin{array}{l}87.667 \pm \\
0.494^{* * *}\end{array}$ & $\begin{array}{l}89.500 \pm \\
0.342\end{array}$ & $\begin{array}{l}89.000 \pm \\
0.258\end{array}$ \\
\hline $\begin{array}{l}\text { Ethanol }(50 \%) \text { treated } \\
\text { group }\end{array}$ & $89.000 \pm 0.258$ & $\begin{array}{l}89.000 \pm \\
0.258\end{array}$ & $\begin{array}{l}88.000 \pm \\
0.101\end{array}$ & $\begin{array}{l}86.000 \pm \\
0.142^{* *}\end{array}$ & $\begin{array}{l}85.000 \pm \\
0.258^{* *}\end{array}$ & $\begin{array}{l}85.000 \pm \\
0.258 * *\end{array}$ \\
\hline $\begin{array}{l}\text { Ethanol }(100 \%) \text { treated } \\
\text { group }\end{array}$ & $87.500 \pm 0.342$ & $\begin{array}{l}84.50 \pm \\
0.342 * *\end{array}$ & $\begin{array}{l}84.50 \pm \\
0.342 * *\end{array}$ & $\begin{array}{l}86.00 \pm \\
0.258 *\end{array}$ & $\begin{array}{l}88.50 \pm \\
0.342\end{array}$ & $\begin{array}{l}86.50 \pm \\
0.342\end{array}$ \\
\hline
\end{tabular}


Table.3 Amplitude of waves after treatment of ethanol (25\%), ethanol (50\%) and ethanol (100\%) (Mean \pm SE)

\begin{tabular}{|c|c|c|c|c|c|c|c|}
\hline & Waves & Control & 10min & 20 min & $30 \mathrm{~min}$ & $40 \mathrm{~min}$ & $50 \mathrm{~min}$ \\
\hline \multirow{3}{*}{$\begin{array}{l}\text { Ethanol }(25 \%) \\
\text { treated group }\end{array}$} & $\mathrm{P}$ & $0.050 \pm 0.00258$ & $0.0250 \pm 0.003^{* *}$ & $0.050 \pm 0.00258$ & $0.050 \pm 0.00258$ & $0.0400 \pm 0.00258$ & $0.0250 \pm 0.00342 * *$ \\
\hline & QRS & $0.145 \pm 0.00342$ & $0.300 \pm 0.00516^{* *}$ & $0.300 \pm 0.00516 * *$ & $0.287 \pm 0.00882 * *$ & $0.248 \pm 0.00654^{* *}$ & $0.200 \pm 0.00516^{* *}$ \\
\hline & $\mathrm{T}$ & $0.650 \pm 0.00342$ & $0.150 \pm 0.00258 * *$ & $0.165 \pm 0.00342 * *$ & $0.650 \pm 0.00342$ & $0.108 \pm 0.00543^{* *}$ & $0.950 \pm 0.00342 * *$ \\
\hline \multirow{3}{*}{$\begin{array}{l}\text { Ethanol }(\mathbf{5 0 \%}) \\
\text { treated group }\end{array}$} & $\mathrm{P}$ & $0.050 \pm 0.003$ & $0.050 \pm 0.003$ & $0.050 \pm 0.003$ & $0.025 \pm 0.003^{* *}$ & $0.020 \pm 0.003 * *$ & NT \\
\hline & QRS & $0.21 \pm 0.003$ & $0.29 \pm 0.007 * *$ & $0.24 \pm 0.007 * *$ & $0.29 \pm 0.007 * *$ & $0.19 \pm 0.003$ & $0.29 \pm 0.00558 * *$ \\
\hline & $\mathrm{T}$ & $0.09 \pm 0.007$ & $0.09 \pm 0.003$ & $0.05 \pm 0.003^{* *}$ & $0.13 \pm 0.003 * *$ & $0.15 \pm 0.003^{* *}$ & $0.18 \pm 0.003 * *$ \\
\hline \multirow{3}{*}{$\begin{array}{l}\text { Ethanol }(\mathbf{1 0 0 \%}) \\
\text { treated group }\end{array}$} & $\mathrm{P}$ & $0.051 \pm 0.00271$ & $0.050 \pm 0.003$ & $0.070 \pm 0.003 * *$ & $0.050 \pm 0.003$ & $0.025 \pm 0.003 * *$ & $0.025 \pm 0.003 * *$ \\
\hline & QRS & $0.242 \pm 0.00543$ & $0.177 \pm 0.00494 * *$ & $0.290 \pm 0.003 * *$ & $0.222 \pm 0.007 *$ & $0.200 \pm 0.005^{* *}$ & $0.150 \pm 0.003^{* *}$ \\
\hline & $\mathrm{T}$ & $0.115 \pm 0.003$ & $0.050 \pm 0.003 * *$ & $0.100 \pm 0.003 * *$ & $0.105 \pm 0.003$ & $0.115 \pm 0.003$ & $0.095 \pm 0.003 * *$ \\
\hline
\end{tabular}

Table.4 Duration of waves after treatment of ethanol (25\%), ethanol (50\%) and ethanol (100\%) (Mean \pm SE)

\begin{tabular}{|c|c|c|c|c|c|c|c|}
\hline & Waves & Control & $10 \mathrm{~min}$ & $20 \mathrm{~min}$ & $30 \mathrm{~min}$ & $40 \mathrm{~min}$ & 50 min \\
\hline \multirow{5}{*}{$\begin{array}{l}\text { Ethanol }(25 \%) \\
\text { treated group }\end{array}$} & $\mathrm{P}$ & $0.0300 \pm 0.00258$ & $0.250 \pm 0.00342$ & $0.0300 \pm 0.00258$ & $0.0300 \pm 0.00258$ & $0.0300 \pm 0.00516$ & $0.0250 \pm 0.00342$ \\
\hline & PR & $0.0400 \pm 0.00258$ & $0.0450 \pm 0.00342$ & $0.0500 \pm 0.00258$ & $0.0500 \pm 0.00258$ & $0.0500 \pm 0.00258$ & $0.0500 \pm 0.00258$ \\
\hline & QRS & $0.0300 \pm 0.00258$ & $0.0300 \pm 0.00258$ & $0.0400 \pm 0.00258$ & $0.0300 \pm 0.00258$ & $0.0400 \pm 0.00258$ & $0.0400 \pm 0.00258$ \\
\hline & QT & $0.140 \pm 0.00258$ & $0.145 \pm 0.00342$ & $0.150 \pm 0.00258$ & $0.130 \pm 0.00258$ & $0.150 \pm 0.00258$ & $0.140 \pm 0.00258$ \\
\hline & $\mathrm{T}$ & $0.0550 \pm 0.00342$ & $0.0550 \pm 0.00342$ & $0.0917 \pm 0.00342 * *$ & $0.0500 \pm 0.00258$ & $0.0800 \pm 0.00258 * *$ & $0.0600 \pm 0.00258$ \\
\hline \multirow{5}{*}{$\begin{array}{l}\text { Ethanol }(50 \%) \\
\text { treated group }\end{array}$} & $\mathrm{P}$ & $0.04 \pm 0.003$ & $0.04 \pm 0.003$ & $0.03 \pm 0.003$ & $0.04 \pm 0.003$ & $0.03 \pm 0.003$ & NT \\
\hline & PR & $0.06 \pm 0.003$ & $0.05 \pm 0.003$ & $0.05 \pm 0.003$ & $0.05 \pm 0.003$ & $0.06 \pm 0.003$ & NT \\
\hline & QRS & $0.03 \pm 0.003$ & $0.03 \pm 0.003$ & $0.03 \pm 0.003$ & $0.03 \pm 0.003$ & $0.03 \pm 0.003$ & $0.03 \pm 0.003$ \\
\hline & QT & $0.12 \pm 0.003$ & $0.11 \pm 0.004$ & $0.13 \pm 0.003$ & $0.14 \pm 0.003^{* *}$ & $0.16 \pm 0.003 * 8$ & $0.15 \pm 0.003^{* *}$ \\
\hline & $\mathrm{T}$ & $0.06 \pm 0.003$ & $0.06 \pm 0.003$ & $0.05 \pm 0.003$ & $0.08 \pm 0.003 * *$ & $0.10 \pm 0.003 * *$ & $0.08 \pm 0.003 * *$ \\
\hline \multirow{5}{*}{$\begin{array}{l}\text { Ethanol }(100 \%) \\
\text { treated group }\end{array}$} & $\mathrm{P}$ & $0.030 \pm 0.003$ & $0.025 \pm 0.003$ & $0.040 \pm 0.003$ & $0.050 \pm 0.003 * *$ & $0.040 \pm 0.003$ & $0.030 \pm 0.003$ \\
\hline & PR & $0.060 \pm 0.003$ & $0.050 \pm 0.003$ & $0.060 \pm 0.003$ & $0.070 \pm 0.003$ & $0.060 \pm 0.003$ & $0.060 \pm 0.003$ \\
\hline & QRS & $0.030 \pm 0.003$ & $0.030 \pm 0.003$ & $0.040 \pm 0.003$ & $0.030 \pm 0.003$ & $0.040 \pm 0.003$ & $0.040 \pm 0.003$ \\
\hline & QT & $0.140 \pm 0.003$ & $0.120 \pm 0.003 * *$ & $0.140 \pm 0.003$ & $0.150 \pm 0.003$ & $0.150 \pm 0.003$ & $0.150 \pm 0.003$ \\
\hline & $\mathrm{T}$ & $0.080 \pm 0.003$ & $0.040 \pm 0.003 * *$ & $0.070 \pm 0.003$ & $0.080 \pm 0.003$ & $0.080 \pm 0.003$ & $0.090 \pm 0.003$ \\
\hline
\end{tabular}

NT-Not traceable 
In contrast there is no change of $\mathrm{P}, \mathrm{P}-\mathrm{R}$ interval and QRS complex measurements in our study. The PR interval reflects the time needed to activate the atria, to conduct the impulse to the AV node and His bundle and start the ventricular depolarization. QRS complex is because of ventricular depolarization. QTC interval in seconds was $0.12 \pm 0.003 ; 0.140 \pm 0.003$ in normal rabbits and $0.15 \pm 0.003 ; 0.150 \pm 0.003$ in $(50 \%$ and $100 \%$ ) ethanol treated animals.

Thus, QT interval was significantly increased, compared with that of control group (50\% treated group). QTC interval in the electrocardiogram includes both ventricular depolarization and repolarization times and varies inversely with the heart rate (Lorsheyd et al., 2005). Alcohol consumption causes ECG changes which include cardiac conduction abnormalities, prolongation of the QT interval, prolongation of ventricular repolarization and sympathetic stimulation (Rossinen et al., 1999). T wave duration were (0.0550 $\pm 0.00342,0.06 \pm 0.003 ; 0.080 \pm 0.003)$ in normal rabbits and $(0.0600 \pm 0.00258$; $0.08 \pm 0.003$ and $0.090 \pm 0.003)$ in $25 \%, 50 \%$ and $100 \%$ treated group respectively.

Therefore, it can be concluded from the present study that ethanol has effect on heart rate controlling and Electrocardiogram of New Zealand White rabbits.

\section{References}

Ahmed, J. A. 2002 Comparative electrocardiography in domestic animals with special reference to cardiac axis in goats. MVSc Thesis, West Bengal University of Animal and Fishery Sciences, Kolkata, India

Ahmed, J.A., Nazki, A.R., Nashirudullah, N., Iqbal. S. and Pampori, Z. A. 2008 Electrocardiographic observations in clinically healthy New Zealand White rabbits. Indian Journal of Animal Physiology. 3: 104-107

Altura, B.M. and Altura, B.T. 1989 Cardiovascular functions in alcoholism and after acute administration of alcohol: Heart and Blood vessels, In: Alcoholism Biomedical and Genetic Aspects. New York; Pregamon:167215.

Bollinger, O. 1884 Uber die Häufigkeit and Ursachen der idiopathischen Herzhypertrophie in München. Deutsche Medizinische Wochenschrift,10 180.

Carmichael, F.J. and Israel, Y. 1975 Effects of ethanol on neurotransmitter release by rat brain cortical, Journal of Pharmacology and Experimental Therapeutics, 193:824-34.

Earleywine, M. and Martin, C. 1993. Anticipated stimulant and sedative effects of alcohol vary with dosage and limb of the blood alcohol curve. Alcoholism Clinical and Experimental Research, 17: 135-139.

Erickson, C.K. and Graham, D.T. 1973. Alteration of cortical and reticular acetylcholine release by ethanol in vivo, Journal of Pharmacology and Experimental Therapeutics, 185: 58393.

Ettinger, P.O., Wu, C.F., DeLaCruz, C.Jr., Weisse, A.B., Ahmed, S.S. and Regan, T.J. 1978. Arrhythmias and the "holiday heart": Alco- hol associated cardiac rhythm disorders. American Heart Journal, 95: 555- 562.

Kitchin, A.H. and Neilson, J.M. 1972.The T wave of the electrocardiogram during and after exercise in normal subjects. Cardiovascular Research, 6(2): 143149

Klatsky, A.L. 1996. Alcohol, coronary disease and hypertension. Annual Review of Medicine, 47: 149-160. 
Langer, R.D., Criqui, M.H. and Reed, D.M. 1992. Lipoprotein and blood pressure as biological pathways for effect of moderate alcohol consumption on coronary heart disease. Circulation, 85: 910-915.

Lorsheyd,A., De Lange, D.W., Hijmering, M.L., Cramer, M.J.M. and VandeWiel, A. 2005. PR and QTC interval prolonga-tion on the electrocardiogram after binge drinking in healthy individuals. Netharland Journal Medicine, 63 (2): 59-63.

Manning, G.V. and Smihley, J.R. 1964. QRSVoltage Criteria for Left Ventricular Hypertrophy in a Normal Male Population. Circulation, 29:224-230.

Marriott, H.J.L. and Myerburg, R.J. 1974. Recognition and treatment of cardiac arrhythmias and conduction disturbances. In The Heart, ed 3, edited by JW Hurst. New York, McGraw-Hill, 502-558.

Park, J.K., Park, J., Uhm, J.S., Joung, B., Lee, M.H. and Hui-Nam Pak, H.N. 2016. Low P-wave amplitude $(<0.1 \mathrm{mV})$ in lead I is associated with displaced interatrial conduction and clinical recurrence of paroxysmal atrial fibrillation after radiofrequency catheter ablation. $E P$ Europace, 18(3): 384-391.

Pope, E.C. and Rowley, A.F. 2002. The heart of Ciona intestinalis: eicosanoidgenerating capacity and the effects of precursor fatty acids and eicosanoids on heart rate, Journal of Experimental Biology, 205: 1577-83.

Ramanna, K., Gahlot, F.M. and Puranik, N. 2015. Electrocardiogram changes and heart rate variability during moderate exercise in chronic alcoholics. International Journal of Medical Science and Public Health, 4(4): 492495.

Robertson, D .1955. The Electrocardiogram in Senile Arterial Disease. Postgraduate Medical Journal, 31(353):121-125.

Rossinen, J., Sinisalo, J., Partanen, J., Nieminen, M.S. and Viitasalo, M. 1999. Effects of acute alcohol infusion on duration and dispersion of QT interval in male patients with coronary artery disease and in healthy controls. Clinical Cardiology, 22: 591-594.

Samonia, G.E. and Hakumaki, M.K.O. 1982. Role of parasympathetic nervous system in alcohol inducded bradycardia in conscious cats. Scandinavian Journal of Clinical Laboratory Investigation, 42(5): 417-422.

Swathi, K. and NasarAhamed, R. 2014. Study ECG Effects in Alcoholic and Normals. Journal of Pharmaceutical Science \& Research, 6(7): 263-265.

Takeda, R., Momose, Y. and Nakanishi, S. 1984. Effects of Ethanol on Calcium and Potassium Currents in Single Bullfrog Atrial Cells. Japanese Journal of Pharmacology, 36: 422-424.

Tilley, L.P. 1979. Essentials of canine and feline electrocardiography. CV Mosby Company, London. 28-34.

Venkateshwarlu, K., Sunder, N.S. and Choudhuri, $\quad$ P.C. 1977. Electrocardiographic observations in healthy dogs. Indian Veterinary Journal, 74: 155-158.

\section{How to cite this article:}

Jafrin Ara Ahmed, Nawab Nashiruddullah, Juneet Kour and Dibyendu Chakraborty. 2019. Acute Effect of Intravenous Ethanol on Electrocardiogram of New Zealand White Rabbits. Int.J.Curr.Microbiol.App.Sci. 8(02): 125-130. doi: https://doi.org/10.20546/ijcmas.2019.802.015 